\title{
THE DOCTRINE OF PARTY AUTONOMY IN INTERNATIONAL COMMERCIAL ARBITRATION: MYTH OR REALITY?
}

\author{
Sunday A. Fagbemi*
}

\begin{abstract}
The increased preference for arbitration has buttressed the growing

1 disenchantment for traditional adversary method of litigation. The foundation of every arbitration proceeding is the arbitration agreement. The parties' agreement constitutes a contract to refer disputes, which have arisen or may arise in future between them to arbitration. The freedom of parties to consensually execute arbitration agreement is known as the principle of party autonomy. The principle provides a right for the parties to international commercial arbitration to choose applicable substantive law and these laws when chosen shall govern the contractual relationship of the parties. However, the pertinent questions have always been: Do parties actually have absolute freedom to determine the arbitration process? To what extent has this been achieved in the resolution of disputes having international concerns? And lastly, is party autonomy a myth or reality? These questions and many others have continued to provoke discussions in many fora on the applicability of party autonomy in international commercial arbitration. To find meaning to the above questions, this article analyses the principle of party autonomy. The ultimate aim of the article is to answer the question whether the practical application of the principle of party autonomy is indeed a myth or reality?
\end{abstract}

Keywords: Party Autonomy, International Commercial Arbitration. doi: http://dx.doi.org/10.4314/jsdlp.v6i1.10

* LL.B (Hons), LL.M (Ife), BL, Senior Lecturer, Department of Public Law, Faculty of Law, University of Ibadan, Ibadan, Nigeria, telephone: 08034709340; 08101800280, e-mail: sakinfagbemilaw@gmail.com. 


\section{INTRODUCTION}

Conflict is unavoidable in human relationships. It is indeed

Whenever there is conflict or dispute it must be resolved one way or the other. For instance, it could be resolved through litigation in the courts or through any of the windows of alternative dispute resolutions mechanisms namely: arbitration, mediation, negotiation or conciliation. If the parties to the dispute fail to select any of the alternative dispute resolution mechanisms, the court would settle their dispute. In view of the adversarial nature of court proceedings and coupled with its rules of technicality, attention is fast shifting from litigation to resolution of disputes by arbitration.

This shift in attention is attributable to several factors, which arbitration has over and above litigation. For instance, arbitration is faster; it is private and confidential; it also promotes friendly atmosphere in the resolution of disputes than litigation. However, prelude to arbitration, the parties must agree on the forms of arbitration, ${ }^{1}$ the procedure to be followed by the arbitral tribunal, place of arbitration and the governing law, etc. The parties are also free to choose the arbitrators, the venue of arbitration, the language to be used during arbitration proceeding and almost everything regarding the resolution of the dispute. ${ }^{2}$ All these are lacking in litigation. More importantly, therefore, arbitration is a private

1 That is, either ad hoc or institution arbitration. See Levi Onyeisi Wilson Odoe, "Party Autonomy and Enforceability of Arbitration Agreements and Award as the Basis of Arbitration” (January 2014) Thesis Submitted for the Degree of Doctor of Philosophy at the University of Leicester 48; Michael Pryles, "Limits of Party Autonomy in Arbitral Procedure" < http://www.arbitration.icca.org/ media/0/12223895489>accessed 30 May 2015.

2 Parties to civil litigation did not have all these opportunities. For instance, in court actions, parties are limited by the substantive law and procedural rules under which their claim is subsumed. Essentially, the applicable law and rules of court determine which court is vested with jurisdiction to entertain civil actions.

3 One fundamental principle of litigation is publicity of trial. The Constitution of the Federal Republic of Nigeria 1999 (as amended), s 36 (1) provides inter alia that "any proceeding whether civil or criminal shall be held in the open court". The objective of this principle is to satisfy the concept of fair hearing that "justice must not only be done, it must be seen to have been done". In the case of Albaji Gaji $v$ The State [1975] NNLR 98. The Nigeria Supreme Court held that: "The test of fair trial must rest on the fair view of a dispassionate visitor to the court who had watched the entire proceedings and it is not possible to say in this case that such a visitor could or would have taken the view that the trial of the accused was anything but fair”. 
court presided over by private judge. ${ }^{3}$ And lastly, the judgment of the arbitrator known as the award is final and binding on the parties.

Arbitration is used for the resolution of varieties of disputes such as: technology, shipping, engineering, oil and gas industries, intellectual property, construction, banking, financial services, securities transactions, real estate, insurance claims and employment grievances among others. ${ }^{4}$ Arbitration may also be domestic or international. International commercial arbitration, which is the focus of this paper, is the most popular method of dispute resolution in international transactions, which transcend national boundaries. The keystone for arbitration is the agreement of the parties to resolve their dispute by arbitration. According to Redfern and others, arbitration agreement requires the parties' consent to submit to arbitration. The consent is indispensable to any process of dispute resolution outside the national courts. ${ }^{5}$ Such agreement is concluded by the parties to submit to arbitration disputes or disagreements which have arisen or which may arise between them in respect of a defined legal relationships, whether contractual or not. ${ }^{6}$ A fundamental principle governing international arbitration agreement is that of party autonomy. According to Ansari, it is the backbone or a cornerstone of arbitration proceeding. ${ }^{7}$

Abdulhay also posits that "party autonomy" is "the freedom of the parties to construct their contractual relationship in the way they see fit". ${ }^{8}$ In other words, it all depends upon the parties themselves to arrange their arbitration agreement freely without any control. The principle of party autonomy is recognized under UNCITRAL Model Law, which

4 Susan Blake and others, A Practical Approach to Alternative Dispute Resolution, (London: Oxford University Press, 2011) 432.

5 Allan Redfern and others, Law and Practice of International Arbitration, (4th edn, London: Sweet and Maxwell, 2004) 131.

6 See United Nations Commission on International Trade Model Law (UNCITRAL Model Law) 1985, art 7; In Reily $v$ Russell [1864] 34 MO 5124 at 528 it was held inter alia that it is fundamental in international commercial arbitration that both parties agree to submit their dispute to arbitration.

7 Jamshed Ansari, "Party Autonomy in Arbitration: “A Critical Analysis” (2014) 6(6)Researcher 47, 53 (ISSN: 1553-9865). <http://www.sciencepub.net/ researcher> accessed 12 August, 2015.

8 Abdulhay, S., Corruption in International Trade and Commercial Arbitration, (London: United Kingdom: Kluwer Law International,2004) 159. 
has been adopted by several countries, including Nigeria, either holistically or with modification. ${ }^{9}$ The Nigeria Supreme Court while describing the principle of party autonomy in the case of $M V$ Lupex $v$ Nigeria Overseas Chartering $E$ Shipping $L t d^{10}$ held inter alia that an arbitration clause is a written submission agreed by the parties to the contract and, like other written submissions, it must be construed according to its language and in the light of the circumstances in which it is made. Thus, the parties have full rights to enter into arbitration agreement to suit their purposes. The principle of party autonomy is by far wider. For instance, under the law of Russian Federation of International Commercial Arbitration, it is stipulated that the arbitration clause, being an integral part of the contract must be construed as the agreement which does not depend on the other terms and conditions of the contract than the will of the parties to it.

Although, the doctrine of party autonomy is a recognized concept in commercial arbitration worldwide, the question as to the extent of freedom or autonomy of party in international commercial arbitration has remained largely unsettled and has been acknowledged as disputable. For instance, questions such as what are the elements constituting a valid arbitration agreement? What is the extent of the principle of party autonomy in commercial arbitration? Or whether parties can agree on any matters they please without restriction are yet to be resolved?

The aim of this article is to evaluate the practicability of the norms of party autonomy in international commercial arbitration. The article is divided into eight sections. Following this introduction is the second section, which discusses the importance of arbitration agreement. Section 3 traces the sources of party autonomy. In its fourth section, the article highlights the rationale for party autonomy, while the concept of party autonomy from various international perspectives is discussed in the fifth section. The sixth section is devoted to the examination of limitations to the doctrine of party autonomy, while section 7 contains recommendations aimed at streamlining the concept of party autonomy with court intervention. Conclusion forms the last section.

9 See the UNCITRAL Model Law, art 19 (1), which provides thus: "Subject to the provision of this Law, the parties are free to agree on the procedure to be followed by the arbitral tribunal in conducting the proceedings:" see also s 1 (b) of the UK. Arbitration Act 1996.

10 [2003] 10 SCM 71 at 79; [2003] 15 NWLR (Pt. 844) 569. 


\section{IMPORTANCE OF ARBITRATION AGREEMENTS}

An arbitration agreement is primarily a substantive contract between the parties to international commercial arbitration. ${ }^{11}$ The agreement is central to arbitration proceedings; hence, its importance has been attributed to many factors. First, it reflects the party autonomy to settle their disputes through arbitration rather than the court of law. Odoe describes arbitration agreement as a binding promise made between two or more parties to a contract to settle the present and/or future disputes through international commercial arbitration instead of dealing with them in the national courts. ${ }^{12}$ Thus, when parties draft an arbitration agreement they enjoy wide freedom to construct a dispute resolution system of their choice. An arbitration agreement, therefore, derives its power from party autonomy.

Second, the essential rule of the principle of arbitration is that where two parties freely enter into an arbitration agreement, there are few restrictions on their freedom to formulate their own terms of the agreement or to design a process, which caters precisely to their needs. ${ }^{13}$ Third, an arbitration agreement precludes judges from resolving the conflicts that the parties have agreed to submit to arbitration. If one of the parties files a lawsuit in relation to those matters, the other may

11 Ar. Gör. ${ }^{a}$ eyda Dursun, “A Critical Examination of the Role of Party Autonomy in International Commercial Arbitration and an Assessment of Its Role and Extent” (2012)<http://www.yalova.ed.tr/Files/User Files/83 /8_Dursun.pdf> accessed 10 August, 2015.

12 Odoe, (n 1) 48; English Arbitration Act 1996 s 6.

13 Odoe ibid; The Nigeria Arbitration and Conciliation Act, 1988 (ACA) s 2 (the Act has been incorporated as Cap A18, Laws of the Federation of Nigeria, 2004 (ACA 2004), which provides thus: "unless a contrary intention is expressed therein, an arbitration agreement shall be irrevocable except by agreement of the parties or by leave of the court or a judge".

14 It should be noted that a judge's lack of jurisdiction is not automatic, nor can it be declared ex officio, rather it must be raised by the defendant not later than when the defendant files his answer to the complaint. This is so because arbitral jurisdiction is waivable and the waiver would be presumed if the plaintiff filed a complaint and the defendant failed to challenge the court's jurisdiction. See, in this connection, the ACA 2004 s 33; the International Chamber of Commerce Arbitration Rules 2012 Art 39; the WIPO Expedited Arbitration Rules 2014 art 54; and the International Centre for Dispute Resolution Arbitration Rules 2014 art 28. 
challenge the court's jurisdiction on the grounds that the jurisdiction of the courts has been waived. ${ }^{14}$ Thus, once a conflict has arisen over any of the subjects included in arbitration agreement, the courts will have no jurisdiction to resolve it unless both parties expressly or tacitly agree to waive the arbitration agreement.

Again, the parties' consent is a basic requirement for the arbitration agreement. Their intention to submit to arbitration must unequivocally arise from the agreement freely entered into by parties. For instance, if one of them has been induced to act against his will as a result of fraud, coercion or undue influence, there has been no real consent and the agreement to arbitrate is invalid. Article 11 (1) of the New York Convention requires inter alia that each contracting state shall recognise an agreement in writing in which the parties undertake to submit to arbitration their disputes. The implication of this provision is understood in two senses. First, it means the agreement must contain a mandatory, rather than permissive, undertaking to submit disputes to arbitration. Second, it means that agreement must provide for arbitration, rather than another process of dispute resolution.

Finally, stressing the importance of party autonomy, Section 51 (2) (a) (ii) of ACA 2004 states inter alia that the recognition and enforcement of foreign arbitration award may be refused if the arbitration agreement is not valid under the law chosen by the parties. ${ }^{15}$

\section{SOURCES OF THE PRINCIPLE OF PARTY AUTONOMY}

Basically, the principle which makes the arbitral process flexible is party autonomy. The principle of party autonomy, in the general sense, started to develop in the 19th century. ${ }^{16}$ Party autonomy is based on choice of law in a contract. However, this principle has broader meaning in international commercial arbitration than in domestic arbitration. In international commercial arbitration, the parties to the arbitration

15 See the New York Convention on the Recognition and Enforcement of Foreign Arbitral, 1958 art V (1) (a). The New York Convention is incorporated into the Nigeria Arbitration and Conciliation Act 2004 as Second Schedule.

16 Dursun, (n 11); Okezie Chukwumerije, AChoice of Law in International Commercial Arbitration (Quorum Books 1994) 161; Dicey and Morris and Collins, The Conflict of Laws, (Vol. 2 14th edn London: Sweet \& Maxwell, 2010) para. 32-004. 
agreement are free not only to choose laws but also to conduct the arbitration process. The parties to an arbitration agreement waive the right to bring an action in court and exclude the jurisdiction of courts by agreement. Arbitration agreement is the primary resource of arbitration and the strongest evidence of party autonomy. ${ }^{17}$

Nearly all international arbitration laws, rules, and conventions recognize the principle of party autonomy. ${ }^{18}$ Thus, arbitration agreement between parties today must include arbitration clauses with an explicit choice of law, and, in keeping with the principle of party autonomy, the parties' choice of law is "invariably" applied by arbitrators. The concept is the high point of the provisions of the Nigeria Arbitration and Conciliation Act, 2004, ${ }^{19}$ the New York Convention, ${ }^{20}$ UNCITRAL Model Law, ${ }^{21}$ the English Arbitration Act, 1996, ${ }^{22}$ Indian Arbitration and Conciliation Act, 1996, ${ }^{23}$ Ghana Arbitration and Conciliation Act, $2010^{24}$ and the International Chamber of Commerce (ICC) Arbitration Rules, $2012^{25}$ just to mention a few. The provisions of the above laws and rules, in varying degrees, explicitly require respect for the parties' choice of procedural provisions. For instance, in the case of the New York Convention, where parties fail to comply with the mandatory provisions laid down by the Convention, an arbitral award may be denied recognition and enforcement by courts. ${ }^{26}$

The reasons for marginalizing the parties' choice of arbitration rules

17 Elizabeth Shackelford, "Party Autonomy and Regional Harmonization of Rules in International Commercial Arbitration” (2006) vol. 67 University of Pittsburgh Law Review 897, 900.

18 Emmanuel Gaillard, "The Role of the Arbitrator in Determining the Applicable Law” in Lawrence W. Newman \& Richard D. Hill (eds), The Leading Arbitrators (Guide to International Arbitration, 2004) 1; Julian D. M. Lew and other, Comparative International Commercial Arbitration (Kluver Law International, 2003) 413.

19 ACA 2004, ss 1 and 2.

20 The New York Convention 1958, art V (1) (d).

21 The UNCITRAL Model Law 1985, art 19 (1), which provides inter alia that:the parties are free to agree on the procedure to be followed by the arbitral tribunal in conducting the proceedings.

22 The English Arbitration Act 1996, s 47.

23 Part I of the Indian Arbitration and Conciliation Act 1996.

24 The Ghana Arbitration and Conciliation Act 2010, s 5.

25 The International Chamber of Commerce (ICC) Arbitration Rules 2012, art 21.

26 The New York Convention 1958, art V.

27 Dursun, (n 11); Gary B. Born, International Commercial Arbitration: Commentary and Materials (2nd edn, 2001) 560; Lew and other, (n 18) 99. 
are not merely in the violation of general principles but could in fact result in the unenforceability of an award. ${ }^{27}$ The authority that parties grant to tribunals is in the form of jurisdiction over particular disputes. One method of conferring jurisdiction on an arbitral tribunal is to include an arbitration clause in the agreement or in a contract between parties. According to Julian Lew, ${ }^{28}$ an arbitration agreement constitutes the evidence of the parties' consent to bestow jurisdiction on a tribunal to decide particular disputes, and one must look to the agreement to determine the extent of jurisdiction that the parties has agreed to concede.

Talking in similar vein, Allan Redfern and others, ${ }^{29}$ posit that because the grant of jurisdiction is voluntary, arbitration tribunals are limited to the scope of jurisdiction specified by the parties. Hence, parties choose to subject disputes to arbitration because they want a neutral and consensual method of dispute resolution. Furthermore, by choosing an arbitration institution at the outset of the agreement, parties can avoid uncertainty and ensure predictability and fairness of a dispute that arises out of the agreement. ${ }^{30}$

The freedom to choose the governing law is a logical extension of party autonomy to agree to submit to a favourable method of dispute resolution. In the words of Arnaldez and others, ${ }^{31}$ "few principles are more universally recognized in private international law" than the principle permitting parties to choose the governing law for their agreements. Parties are able to better control the dispute resolution process by selecting appropriate and favourable laws to apply to their dispute, and are thus able to avoid being subjected to inappropriate or unfavourable laws at a later time. ${ }^{32}$

\section{RATIONALE FOR PARTY AUTONOMY}

A basic principle in international commercial arbitration is that of party autonomy. ${ }^{33}$ The authors, Redfern and others, describe it in the following terms:

28 Lew and others, ibid 100.

29 Redfern and others, (n 5) 248.

30 Dursun, (n 11).

31 Jean-Jacques Arnaldez, Final Award in ICC Case No. 6379 of 1990, (in 3 Collection of ICC Arbitral Awards, 1997) 134: 136.

32 Lew and others, (n 18) 413.

33 Pryles, (n 1) n. 1. 
Party autonomy is the guiding principle in determining the procedure to be followed in an international commercial arbitration. It is a principle that has been endorsed not only in national laws, but by international arbitral institutions and organisations. The legislative history of the Model Law shows that the principle was adopted without opposition.... ${ }^{34}$

Pursuant to the provision of Article 19(1) of the UNCITRAL Model Law, parties are free to agree on the procedure to be followed by the arbitral tribunal in conducting the proceedings. While highlighting the rationale for party autonomy, section 1(b) of the English Arbitration Act 1996 provides that "the object of arbitration is to obtain the fair resolution of disputes by an impartial tribunal without unnecessary delay or expense and as such safeguards as are necessary the public interest". Section 1(c) of the English Arbitration Act also forbids the court from interfering with the party agreement. Dursun summarizes the rationale for party autonomy in the following terms:

The parties to an international commercial contract do not want to resolve their disputes through litigation, since the court, which is national of a party may be foreign of another party. In addition to this, the parties do not want to deal with procedural formalities. Consequently, the parties choose arbitration as a private dispute settlement and thus, they can conduct all proceedings of arbitration by taking into account their needs and desires such as they can arrange timetable of hearings, choose anyone as an arbitrator who have relevant expertise on specific requirements of the dispute. ${ }^{35}$

The above, arguably, captures the rationale for party autonomy in international commercial arbitration.

\section{PARTY AUTONOMY FROM THE INTERNATIONAL PERSPECTIVE}

It is general knowledge the world over that parties are free to choose laws that would determine the arbitral process. The need to avoid all the dramas usually associated with courtroom proceedings has made parties

34 Redfern and others, (n 5) 315.

35 Dursun (n 11) 169. 
embrace a system which allows them to exercise their will and choose laws that are most favourable to them. Party autonomy has gained acceptance in international law and has received recognition in almost all national jurisdictions. ${ }^{36}$ The principle gives freedom to parties to international commercial agreement to choose applicable substantive law and these laws when chosen, govern the contractual relationship of the parties. The parties may also choose to rely on trade usage, a national rules of law, transnational law, lex mercotoria (the law merchant), general principles of law or general principles of international law. ${ }^{37}$

According to Odoe, the written texts of most sections of the ACA and that of some International Arbitration laws show legislative intention for the courts to respect the principle of party autonomy, so far as it is consistent with the requirements of public policy. ${ }^{38}$ In the simplest of terms, the principle of party autonomy as a key characteristic of arbitration means that parties must have the substantial autonomy and control to decide how their arbitrations are to be conducted without the court interfering except for the purpose of supervision and enforcement of the arbitral award. For avoidance of doubt, the relevant provisions of few arbitration laws are highlighted below.

\subsection{Party Autonomy Under the Nigeria Arbitration and Conciliation Act}

In Nigeria, the Arbitration and Conciliation Act 2004 governs arbitration proceeding and Arbitration Rules made thereunder. ${ }^{39}$ Reinforcing the principle of party autonomy, section 2 of the ACA provides that:

Unless a contrary intention is expressed therein, an arbitration agreement shall be irrevocable except by the agreement of the parties or by leave of the court or a judge.

36 Chukwumerije, (n 16) 105-106.

37 Redfern and others, (n 5) 98.

38 Odoe,(n 1) 79.

39 The Rules is the First Schedule to Arbitration and Conciliation Act, 2004; See also Ojukwu Ernest and Ojukwu Christopher N., Introduction to Civil Procedure (3rd edn., Abuja: Helen-Roberts Ltd 2009) 301; Idornije Pius O, “Towards Successful Arbitral Proceedings; How to manage the process" (2004) vol. 2 No. 4, Nigeria Bar Journal, 395-412.

40 J. Olakunle Orojo and M. Ayodele Ajomo, Law and Practice of Arbitration and Conciliation in Nigeria (Lagos: Mbeyi \& Associates (Nigeria) Limited, 1999), 29. 
Parties to arbitration process are free under Nigerian law to choose the applicable law to their transaction. ${ }^{40}$ For instance, Article 47(1) of the Arbitration Rules state that: "the arbitral tribunal shall decide the dispute in accordance with the rule in force in the country whose laws the parties have chosen as applicable to the substance of the dispute". With this provision, it is submitted that the principle of party autonomy largely influences the choice of law applicable to the dispute. Again, Section 47(4) of the ACA 2004 makes it clear that the tribunal shall not decide ex aequo et bono or amiable compositeur, unless the parties have expressly authorized it to do so. Furthermore, in Section 47(5) of the ACA 2004, it is clear that in all cases, the arbitral tribunal shall decide in accordance with the terms of the contract and shall take into account the usages of the trade applicable to the transaction.

Apart from the above provisions, the Nigeria Arbitration Act, in recognition of the principle of party autonomy further confers on parties the freedom to resolve by agreement the number of arbitrators and their appointment, ${ }^{41}$ place of arbitration ${ }^{42}$ and language to be used in arbitral proceedings. ${ }^{43}$ The freedom to choose the applicable law is very fundamental; the reason being that the dispute will be decided in accordance with the law chosen by parties, since the parties are bound by the law that they have chosen. ${ }^{44}$ The principles of the ACA in section $47(6)^{45}$ can be compared with the provision of Article 3 of the Uniform law 1964 on the International Sale of Goods, which provides that although the uniform law was to govern international sales, the parties to a contract are free to exclude the application of the Uniform Law. ${ }^{46}$ While Article 3 talks about the freedoms; Article 9 of the Uniform Law talks about the obligations in which it provides that the parties shall be bound by any usage which they have expressly or impliedly made a choice of law to their contract. Furthermore, this provision is similar to the provision under the Benelux Uniform law relating to private International law,

41 ACA 2004, ss 6 and 7.

42 Ibid s 16.

43 Ibid s 18,

44 Julian D. M. Lew, Applicable Law in International Commercial Arbitration (Oceana, 1978) para 439.

45 ACA 2004, s 47 (6) provides that: "If the arbitration law of a country where the award is made requires that the award be filed or registered by the arbitral tribunal, the arbitral tribunal shall comply with this requirement within the period of time required by law."

46 Odoe (n 1) 83.

47 ibid. 
which stated in Article 13(1) that contracts are governed by both the imperative and the subsidiary provisions of the law chosen by the parties. ${ }^{47}$

\subsection{Party Autonomy Under the UNCITRAL Model Law}

One of the objectives of the UNCITRAL Model $\mathrm{Law}^{48}$ is the liberalization of international commercial arbitration by limiting the role of national courts and by giving effect to the doctrine of "autonomy of the will", allowing the parties freedom to choose law under which their disputes should be determined. ${ }^{49}$ However, according to Agarwal, the Model Law does not, and was not intended to grant absolute autonomy to parties over the conduct of arbitration. It was meant to promote general autonomy to parties but balanced with safeguards in the form of mandatory provisions that could not be contracted out on the basis that these were considered to be essential to the arbitration regime. ${ }^{50}$ There is, however, no express listing or delineation of which provision is considered to be mandatory provisions of the Model Law. A couple of provisions, which appear to be mandatory, are:

Article 7(2), which provides for arbitration agreements to be in writing, Article 18, which provides for the equality treatment of parties during arbitral proceeding and for the party to be given a full opportunity of presenting his case. Article 24(2) (3) states that party shall be given notice of any hearing and be sent any materials supplied to the arbitral tribunal by the other party while, Article 31(1) (3) (4) provide that an award shall be in writing, stating its date and place and that it be delivered to the parties.

The above provisions determine the essential validity of arbitration agreement, without which, an award made pursuant to parties' agreement will be denied recognition and enforcement. The principle of party autonomy was addressed under Article 19(1) of the UNCITRAL Model Law, which provides thus: "subject to the provisions of this law, the parties are free to agree on the procedure to be followed by the arbitral tribunal in conducting the proceedings." Reinforcing this provision, Article 5(1)

48 The UNCITRAL Model Law of International Commercial Arbitration was adopted by the UN General Assembly on 21st June, 1985.

49 Orojo and Ajomo, (n 40) 19.

50 Anurag K. Agarwal, "Party Autonomy in International Commercial Arbitration" (May 2007)Indian Institute of Management, Ahmedabad, India Research and Publications 7. 
of the Model Law states inter alia that "in matters governed by this law, no court shall intervene except where so provided in this law.”

The above provisions buttress the importance of party autonomy in international commercial arbitration. However, when the parties have not made a choice of law, the arbitrators must apply "the law" designated by applicable conflict rules. This implies that the arbitrators are obliged to identify a law of a particular country. The arbitrators are further obliged to use conflict rules; they cannot apply a substantive law directly. A large number of Articles of the Model Law include phrases such as "unless otherwise agreed by the parties”. Such phrases, according to Agarwal, describe the non-mandatory nature of these articles. However, it does not mean that all other articles are mandatory. Thus, it is not possible for parties to determine with certainty which provisions of the Model Law are non-derogable. ${ }^{51}$

Article 4 of the Model Law provides for waiver of the right to object to non-compliance with any provision, which apparently would refer to non-mandatory provision. As the Model Law does not contain a list of mandatory provisions, to which provisions exactly would apply? Waiver of a party's right to object goes to the root of the legal strategy of the party and it is more disturbing as the article mentions that this happens with the knowledge of the party that the provision is derogable. For instance, under Article 19 of the Model Law, the parties are free to agree on the procedure to be followed by the arbitral tribunal in conducting the proceedings. Failing which the arbitral tribunal may, conduct the arbitration in such manner, as it considers appropriate. The implication of this provision is that parties can only agree to rules of procedure to the extent that they do not conflict with mandatory provisions of the Model Law.

Another notable provision of Model Law touching on party autonomy is the provision of Article 34(2), which provides for the setting aside of the arbitral award if: the party making the application furnishes proof that the composition of the arbitral tribunal or the arbitral procedure was not in accordance with the agreement of the parties or was in conflict with a provision of the Model Law from which the parties cannot derogate. These provisions contain practical restriction on the autonomy of the parties, which will be discussed later.

51 ibid. 


\subsection{Party Autonomy Under the New York Convention}

The New York Convention is the United Nations Convention on the Recognition and Enforcement of Foreign Arbitral Awards. ${ }^{52}$ The Convention took place in 1958 but came into force on 7 June 1959. The Convention is concerned with the enforcement of foreign awards, which is one of the main reasons parties find the law attractive. It recognizes party autonomy in the agreement made in writing by the parties where they agree to submit to arbitration all or any of their differences, whether presently or in the future..$^{53}$ This agreement forms the basis for the recognition and enforcement of arbitral award and a party shall at the time of application, supply the original agreement or a duly certified copy of it. ${ }^{54}$ The New York Convention also stipulates grounds on which recognition and enforcement may be denied an award in its Article V, these grounds constitute limitations to party autonomy.

\subsection{Party Autonomy Under the International Chamber of Commerce (ICC) Arbitration Rules, 2012}

The ICC Arbitration Rules provides for dispute resolution procedure similar to the New York Convention. This procedure is to lead to a binding decision from the neutral arbitral tribunal appointed by the parties to arbitration. The intention of the ICC Rules is to ensure transparency, efficiency and fairness in the dispute resolution process while allowing parties to exercise their choice over many aspects of procedure. ${ }^{55}$

52 It is otherwise called New York Convention. The Convention is set out in the Second Schedule to the Nigeria Arbitration and Conciliation Act, 2004. The Convention was made in June 1958 but was not open for signature until 31 December 1958. Nigeria acceded to the Convention on 17 March 1970. The Convention has been made expressly applicable to Nigeria by section 54 of the Nigeria Arbitration and Conciliation Act, 2004; Orojo and Ajomo, (n 40) 16.

53 New York Convention art II (1); Egbedi Tamara, An Analysis of The Effect of Public Policy on Party Autonomy in International Arbitration.<http:// www.pdfebooksdownloads.com/Party-Autonomy-in-Arbitration.html> accessed on 14 August 2015, 14.

54 New York Convention 1958, art IV (1) (b).

55 See the introduction to the Booklet of ICC Arbitration Rules, 2012, $<$ www.iccwbo.org>. The ICC Arbitration Rules has been severally amended. For instance, it commences in 1975, but in 1998, ICC adopted new rules which further freed the arbitrators in the process of determining which law is applicable. The current one in operation is the ICC Arbitration Rules, 2012. 
Under the Rules, parties are free to determine the law to be applied by the arbitrators to the merits of the dispute. However, in the absence of any indication by the parties as to the applicable law, the arbitrators shall apply the rules of law which it determines to be appropriate. ${ }^{56}$ Here, the only requirement is that the arbitrators should consider the application of the selected conflict rules "appropriate" in the particular situation. The use of the term "appropriate" suggests that some form of justification or connection to the specific case had to be made. In addition, the arbitral tribunal shall take account of the provision of the contract, if any, and of any relevant trade usages. ${ }^{57}$

\subsection{Party Autonomy Under the United Kingdom Arbitration Act, 1996}

The UK Arbitration Act takes a less flexible approach than most other national Arbitration Acts. Section 46(1) of the Act provides inter alia that "the arbitral tribunal shall decide the dispute in accordance with the law chosen by the parties as applicable to the substance of the dispute; or if the parties so agree, in accordance with such considerations as are agreed by them". In case parties did not agree on any such choice of law, Section 46(3) of the Act provides for the alternative in the following terms: "if or to the extent that there is no such choice or agreement, the tribunal shall apply the law determined by the conflict of laws rules which it considers applicable."

Based on the above provision, the arbitrators are required to apply rules to identify the apposite law. The term "law" rather than "rules of law" implies that a whole system of law must be chosen; and an application of rules from various systems appears to be prohibited. Despite the mentioned law, the Act still states that "the parties should be free to agree how their disputes are resolved, subject only to such safeguards as are necessary in the public interest." ${ }^{5}$ The first part confirms the party autonomy principle as parties are free to agree on the choice of law, seat of arbitration and the procedure to be followed. One can see that this principle is evident in this Act because words like "the parties are free to

56 ICC Arbitration Rules of 2012, art 21 (1).

57 Ibid, art 21 (2).

58 ACA 2004, s 1(b).

59 Dursun,(n 11) 163. 
agree" or "unless the parties otherwise agree" or "unless otherwise agreed by the parties" demonstrate party autonomy..$^{59}$

\subsection{Party Autonomy Under the Indian Arbitration and Conciliation Act, 1996}

The principle of party autonomy can be drawn from Part I of the Indian Arbitration and Conciliation Act 1996. Just like the provision of Section 46 of the English Arbitration Act, 1996, Part I of the Indian Act provides that in determining the rules of law applicable to the substance of the dispute, the arbitral tribunal shall decide the dispute in accordance with the rules of law designated by the parties as applicable to the substance of the dispute and, failing any such designation, the rules of law the tribunal considers appropriate given all the circumstances. ${ }^{60}$ While interpreting this provision, the Indian Supreme Court in the case of Bhatia International v. Bulk Trading $S A,{ }^{61}$ held that Part I of the Indian Act applied to arbitrations which took place outside India, including foreign awards, unless the parties expressly or impliedly excluded all or any of its provisions.

In recognition of party autonomy to determine arbitration process, section 8 of the Indian Arbitration and Conciliation Act confers on the court power to refer parties to arbitration where their agreement so stated. The Section 8(1) of the Act, in unmistaken terms provides that: "a judicial authority before which an action is brought in a matter which is the subject of an arbitration agreement shall, if a party so applies not later than when submitting his first statement on the substance of the dispute, refer the parties to arbitration." Thus, notwithstanding that an application is pending before a judicial authority as stated above, arbitration may be commenced or continued and an arbitral award made. ${ }^{62}$

Furthermore, by virtue of Section 20 of the Indian Act, the parties are free to agree on the place of arbitration, failing which the arbitral tribunal shall determine, the place of arbitration. In doing this, regard must be had to the circumstances of the case, including the convenience of the parties. ${ }^{63}$ However, in spite of this provision, it appears that the

60 Indian Arbitration and Conciliation Act 1996, s 2 (4).

61 [2002] INSC 132.

62 Indian Arbitration and Conciliation Act 1996, s 8 (3).

63 Ibid s 20 (2).

64 Ibid s 20 (3). 
arbitral tribunal may meet at any place it considers appropriate for consultation among its members, for hearing experts or the parties, or for inspection of documents, goods or other property. ${ }^{64}$ This nonmandatory section of the Indian Arbitration Act, according to Odoe, ${ }^{65}$ can be compared with the non-mandatory sections of the English Arbitration Act 1996. For instance, section 3 of the English Arbitration Act, which provides for the seat of arbitration states that "the seat of the arbitration means the juridical seat of the arbitration designated (a) by the parties to the arbitration agreement, or (b) by any arbitral or institution or person vested by the parties with powers in that regard, or (c) by the arbitral tribunal if so authorized by the parties; or determined, in the absence of any such designation, having regard to the parties' agreement and all the relevant circumstances".

The conclusion to be drawn from the above scenario is that, with the principle of party autonomy, parties are free to designate the seat of arbitration themselves or in some other manner authorized by them. Thus, where a conflict of laws embraces the principle, the principle is upheld leaving the parties to determine for themselves their choice of law rather than one imposed on them.

\subsection{Party Autonomy Under the Ghana Arbitration and Conciliation Act, 2010}

The main principle of arbitration enshrined in Ghana Arbitration and Conciliation Act 2010 is the general principle of party autonomy, respecting and securing the ability of parties to choose how to deal with the disputes between them, such as by arbitration and how such arbitration should be conducted. As a preliminary issue prelude to arbitral process, Section 5(1) of the Ghana Act provides that a party to a dispute in respect of which there is an arbitration agreement may, subject to the terms of that agreement, refer the dispute to arbitration. This section forms the basis for arbitration; hence, in the absence of arbitration clause in the parties' agreement, their right to refer their dispute to arbitration is foreclosed. Sections 12 to 14 of the Ghana Arbitration Act further reinforce the above provision by giving additional freedom to parties to agree on the identity and make-up of the tribunal, stipulate any requirements as to the arbitrator or arbitrators' experience, qualifications

65 Odoe (n 1) 86. 
or nationality, designate an appointing authority, determine the number of arbitrators and determine procedure for appointment. Furthermore, by virtue of Section 48(1) (a) of Ghana Arbitration Act, the arbitral tribunal is required to decide the dispute in accordance with the law chosen by the parties and as applicable to the substance of the dispute.

Consequent to the various statutory provisions highlighted above, it is submitted that the freedom of the parties in international commercial arbitration to decide the substantive law as well as allied matters applicable to their contract are expressly recognized worldwide. However, these freedoms are not cast in iron; they admit some limitations. These limitations are discussed in the next section.

\section{LIMITATIONS TO PARTY AUTONOMY}

As highlighted in the preceding sections, parties to arbitration agreement enjoy maximum autonomy to determine how their dispute is to be resolved. For instance, they can, by agreement, exclude the jurisdiction of the court and can conduct the arbitral proceedings in whatever way that they like. However, the question is whether party autonomy is absolute without limitation? Alternatively, is party autonomy to international commercial arbitration a myth or reality? Without doubt, parties to arbitration enjoy certain degrees of freedom given that the arbitration agreement, which is the foundation of any arbitral processes, is the product of parties' consensual agreement. However, their autonomy is subject to several limitations. For instance, there are certain basic principles, which parties to arbitration cannot statutorily ignore or violate under any situation. These provisions are subtly codified in the various sections of ACA 2004, UNCITRAL Model Law, various Arbitration Laws as well as the principles of natural justice which are applicable to all judicial and quasi-judicial authorities and tribunals. ${ }^{66}$

For instance, Section 14 of the Nigeria Arbitration and Conciliation Act 2004, which is a replica of Article 18 of the UNCITRAL Model Law, provides that: "the parties shall be treated with equality and each party shall be given a full opportunity of presenting his case." The implication of this provision are as follows: First, that arbitration agreement is the

66 Arbitration process is by nature quasi-judicial proceedings and is bound to follow the principle of natural justice. See Jamshed Ansari, (n 7) 50. See also S.K. Agarwal, "Arbitration: An option to resolve under Section 89 of CPC" (2003) AIR 187. 
making of the parties to arbitration, however, in the conduct of the arbitral proceedings they are entitled to equal treated, failing which, there is no justice. Secondly, each party shall be given full opportunity to present their case completely. Thus, where any of the party is not given proper notice of the arbitral proceeding or otherwise denied the opportunity to present the case before the arbitral tribunal, the resulting award will be annulled when challenged. ${ }^{67}$ Thirdly, Arbitration tribunal being a quasijudicial authority, the judges should not be appointed as arbitrators. ${ }^{68}$ To safeguard the principle of natural justice, all judicial as well as administrative authorities are required to follow the principle of natural justice in the course of proceedings before them. ${ }^{69}$ In the case of D.C. Saxena $v$ State of Haryana, ${ }^{70}$ it was held that if the statute is silent on the matter, the natural justice principle has to be followed.

The principles which constitute the essential norms of Arbitration and which characterize the principle of natural justice are as follow:

i. Nemo judex in causa sua, i.e. no man shall be a judge in his own cause.

ii. No party shall be condemned unheard; that is, each party must be given the opportunity to cross-examine witnesses examined by other side.

iii. Each party is entitled to know the reasons for the decisions.

iv. The person who hears the case must decide finally. If the principle of natural justice is violated while deciding the case,

67 ACA 2004, s 52 (2) (iii); UNCITRAL Model Law, art 36 (2) (ii).

68 Jamshed Ansari, (n 7) 50; R.S. Bachawat, Law of Arbitration and Conciliation, (Nagpur, Wadhwa \& Co. 1999) 414.

69 See the Indian case of Indu Ramchandra Bharwani v UOI [1988] 4 SCC 1. In the case of Judicial Service Commission of Cross River State E Otherv Dr. (Mrs) Asari Young [2013] 2 SCM 98 at 111-112, the Nigeria Supreme Court held inter alia that the principle of fair hearing are as binding on administrative bodies and tribunals of inquiry as they are on the courts. Hence, it is basic that where a body, whether judicial, quasi-judicial, Administrative or Executive in inception, acts judicially in the sense that it is to determine the civil rights and obligations of a person, or to find him guilty or liable of a fault, he must be given a hearing before the issue can be properly decided. See further the Constitution of the Federal Republic of Nigeria, 1999 (as amended), s 36 (1).

70 AIR [1987] SC 1463.

71 See the cases of Baba v N.C.A. T. C [1991] 5 NWLR (Pt. 192) 388and P. H. M. B. v Edna [2001] 5 NWLR (Pt. 707 612; [2001] 4 SCM, 159. 
then the award shall be deemed to be reached without jurisdiction and, hence, annulled. ${ }^{11}$

As corollary to party autonomy are the requirements for the validity of the arbitration agreement itself. Arbitration agreement shares elementary factors with simple contract. Consequently, any factor, which will vitiate ordinary contract will invariably vitiate arbitration agreement and render it unenforceable. For instance, under various arbitration rules, before an arbitration proceeding is adjudged valid, the parties to arbitration agreement must possess the capacity to execute the agreement, the dispute to which it relates must arise out of a legal relationship whether contractual or not, ${ }^{72}$ the arbitration agreement must not be null and void, inoperative and incapable of being performed..$^{73}$ The absence of any of these factors is a fundamental issue vitiating the validity of arbitration agreement and, hence, constitutes limitations to party autonomy as it may be invoked to render the resulting award unenforceable.

In addition to the foregoing, there are some basic mandatory provisions limiting party autonomy to arbitration. These provisions are contained in various Arbitration Laws. In Nigeria, the following factors, among others, are mandatory under the ACA 2004:

i. Arbitration agreement must be written; ${ }^{74}$

ii. The parties shall be treated equally and given full opportunity to present their case; ${ }^{75}$

iii. Parties must be allowed to exchange their statements of claim and statements of reply during arbitration proceedings; ${ }^{76}$

iv. Advance notice of tribunal must be given to the parties and such statement communicated to the parties; ${ }^{77}$

v. The award under Arbitration law is equated with an ordinary award; ${ }^{78}$

vi. Arbitration award must be in writing and signed by the arbitrator and copy delivered to the parties. ${ }^{79}$

72 UNCITRAL Model Law, art II (1) and V (2).

73 See the case of Union of India v McDonnel Douglas Corp. [1993] 2 Lloyd's rep, 48.

74 ACA 2004, s 1; UNCITRAL Model Law, art 7 (1).

75 ACA 2004, s 18; UNCITRAL Model Law, art 18.

76 ACA 2004, s 19.

77 ACA 2004, s 20 (2) (3); UNCITRAL Model Law 1985, art 24 (2) (3).

78 ACA 2004, s 25 (1); UNCITRAL Model Law 1985, art 30(2).

79 ACA 2004, s 26; UNCITRAL Model Law 1985, art 13. 
Failure to comply with the above provisions will affect the resulting award and render it null and void.

Again, parties to arbitration are of necessity expected to choose the law applicable to the substance of their transaction while executing the contract $^{80}$ and the arbitrator has the duty to apply the chosen law to the substance. However, where the choice of law is not made bonafide, the arbitrator may disregard this duty. ${ }^{81}$ Matters like this usually arise during the enforcement or recognition of the awards. ${ }^{82}$ Moreover, the parties are free to agree on the law applicable to arbitration and arbitration agreement. This choice may be subject to the restrictions imposed by the law of the place of arbitration (lex arbitri), since every state wants to regulate any legal activity within the boundaries of their own country. A major reflection of lex arbitri is that the parties can confer some powers upon the arbitral tribunal more than what the lex arbitri allows, such power, when it could not be exercised by the arbitral tribunal, will be exercised by national courts and contrary to the wish of parties. ${ }^{83}$

The issues relating to third parties constitute another restriction on party autonomy. Actually, the arbitration agreement binds only the parties. Thus, the parties cannot agree on anything which can affect the third parties directly. ${ }^{84}$ It follows that where parties have conferred such power upon the arbitral tribunal, the arbitrator cannot compel the third parties to attend the hearings as witnesses ${ }^{85}$

International commercial arbitration recognizes that the courts shall not interfere in arbitral proceedings ${ }^{86}$ This is fundamental to the process. Notably, the court, in the following circumstances, among others, would intervene to assist the parties in the arbitral process. First, a court before which an action is brought in a matter which is the subject of an arbitration agreement shall, if a party so requests, not later than when submitting his first statement on the substance of the dispute, refer the parties to arbitration unless it finds that the agreement is null and void, inoperative

80 Redfern and others, (n 5) para 3.98 and 3.99.

81 Chukwumerije, (n 16) 109.

82 Dursun,(n 11) 169.

83 ibid.

84 Redfern and others, (n 5) para 6.18.

85 ibid, para 6.19.

86 UNCITRAL Model Law art 5; ACA 2004, s 34.

87 UNCITRAL Model Law 1858, art 8(1) (2). 
or incapable of being performed. ${ }^{87}$ Second, parties must agree as to the appointment of arbitrators but where there is a disagreement, an arbitration institution or a court may appoint arbitrators upon request of a party. ${ }^{88}$ Third, the court may order the interim measures upon request by the parties if it is compatible with an arbitration agreement and where it is ascertained that the object of the dispute is a perishable item and it is better to dispose of it to convert to money. ${ }^{89}$

Furthermore, the procedure for challenging an arbitrator may be agreed on by the parties such as agreeing on using the arbitration procedure rules of a certain arbitration institution. But where this fails, a challenging party may request a court or other authority to decide on the challenge. ${ }^{90}$ An award as the final decision of the arbitral tribunal is expected at the end of the arbitral proceedings. In reviewing the arbitral award, it has been argued whether arbitral award is subject to judicial review or not. ${ }^{91}$ It was argued further that, if judicial review is allowed, finality and independence of the arbitral award is not guaranteed and party autonomy is restricted. This is like subjecting an award to the power of the court. However, where parties fail to follow the acceptable standard in the arbitration agreement, the court will intervene to review the award.

Finally, the principle of public policy has been considered to be a major limitation to party autonomy in international commercial arbitration. ${ }^{92}$ The term "public policy", according to Ansari, is a sociological concept which comprises the society's culture, moral values, belief etc., which is accepted and applied in the society. ${ }^{93}$ Public policy is dynamic in nature and it varies with time and place. Many countries have accepted it as a fundamental principle of the country and; hence, any violation of this principle will lead the order or award as null and void. In the case of arbitration proceedings, it provides limit on the party autonomy. It is a good ground for challenging the award and then makes the award unenforceable. The judiciaries of different nations have interpreted the expression "public policy" in different ways.

88 Ibid art 11.

89 Ibid art 9; Okuma Kazutake "Arbitration and Party Autonomy" (2005) The Seinan Law Review, <http://www.einan-gu.ac> accessed on 15th August, 2015.

90 UNCITRAL Model Law art 13.

91 Ibid art 14.

92 Odoe, (n 1) 99.

93 Jamshed Ansari, (n 7) 52.

94 [2000] 3 Arb. L.R. 674. 
The public policy, as a concept, is very vague in nature, however the Supreme Court of India in the case of Bharat Heavy Electricals $v$ C.N. Garg, ${ }^{94}$ has interpreted "contrary to public policy" to mean any agreement that is against "the fundamental policy of the country", "interest of the country", "morality", "justice" and "legal norms". Thus, the term "public policy" has been generally accepted as any conduct, which violates fundamental conceptions of legal order in the country concerned..$^{95}$ While international commercial arbitration supports party autonomy, where such autonomy is exercised contrary to public policy, the award shall be regarded as null, void and of no legal effect whatsoever.

Due to the importance of public policy as limitation to party autonomy in commercial arbitration, Tamara ${ }^{96}$ has listed the following reasons in its favour:

1. It prevents parties from using arbitration to legitimize illegal and immoral contracts. Thus protecting the integrity of arbitration.

2. It acts as a limit to party autonomy, which may likely be abused by the parties.

3. It protects the society from any violation of its fundamental principles.

4. It serves the purpose of permitting the judge of a state not to give effect to an award that would contradict the fundamental principles of the judges' social system.

5. It serves as a ground for the non-recognition and nonenforcement of an award.

Premised on the foregoing analysis, it is submitted that the principle of party autonomy is a good and acceptable principle and makes international commercial arbitration attractive. In the same vein, it is submitted that allowing parties to exercise this freedom without restriction will lead to an abuse of the law and its processes. It is on this note that one cannot, but appreciate the development of various means such as

95 Martin Hunter and Gui Conde E. Silva "Transactional Public Policy and its Application in Investment Arbitrations" < http://www.arbitration.icca.org> accessed on 20th December, 2014 citing Picter Sundeix, Commentary, in 60 years of ICC arbitration, ICC Publishing, Paris, 1984.

96 Egbedi Tamara, (n 53) 11. 
public policy and non-arbitrability of arbitration clause, etc., to checkmate the principle of party autonomy.

\section{RECOMMENDATIONS}

The application of the principle of party autonomy, to determine the freedom of the parties to agree on the procedure to be adopted in arbitration, can be a complex matter. When we imagine international commercial arbitration as a drama, the principle of party autonomy lies at the centre of the arbitration process. In the context of party autonomy, the parties can choose applicable laws and conduct the arbitration process such as the determination of the composition of the arbitral tribunal, language of arbitration, place of arbitration and the law to be applied to the arbitration proceedings, among others things. In order words, the principle of party autonomy allows the parties to determine all the essential elements of the arbitration.

The principle of party autonomy is thus the distinctive aspect of arbitration from other alternative dispute resolution mechanisms; it plays the most important role during the whole arbitration process. As to the extent of party autonomy, it is a principle based on the freedom of contract. The parties can exercise this freedom at every stage of the international commercial arbitration. Nonetheless, the principle is not unlimited and, as discussed in this article, it is subject to restriction in some circumstances. For instance, to checkmate the excesses of parties to commercial arbitration, courts have been given power to intervene where the procedures adopted by parties or the resulting award therefrom are contrary to public policy. In principle, the court always intervenes to ensure that the arbitration agreement is valid and in accordance with the law which governs it and that the parties' agreement is not contrary to public policy. Again, the violation of the principle of natural justice and non-arbitrability of arbitration agreement among other things are factors evolved to act as checks and balances on the principle of party autonomy, thus restricting them from executing agreement that may affect public interest.

In order to streamline the principle of party autonomy viz-a-viz the court's intervention in deserving cases, the following recommendations are essential. First, in as much as it is practicable, parties' agreement should supersede and must be given priority at all times; hence, court intervention should be limited to only where parties' agreement is unenforceable by any standard or where it is intended to be used as instrument of fraud. 
Second, in cases where the parties could not establish the applicable procedural rule but require the consent of the arbitral tribunal, the arbitral tribunal should be cautious before it seeks to impose a rule at variance with that agreed upon by the parties. To this extent, in deciding whether to make an order in terms of the parties' agreement, the tribunal should carefully consider the reasons underlying the parties' agreement in so far as it is aware of them. Finally, since it is private complaint that usually sets court's intervention in motion, courts must be circumspect in intervening in the matter unless the applicant convinces the court of the injustice he has suffered or may suffer under the arbitral agreement executed by the parties.

\section{CONCLUSION}

The principle of party autonomy is a strong weapon in the hands of parties to arbitration. The Nigeria Arbitration and Conciliation Act 2004, the UNCITRAL Model Law as well as other legal regimes designed after the model law, support the principle of party autonomy. The principle is widely accepted in international commercial arbitration as a key element in all arbitration agreements and as an effective tool in promoting and protecting the interests of parties to commercial arbitration. While so much has been said in retaining this principle in commercial arbitration, it is noted that "party autonomy" is not synonymous with "unlimited power" or "complete autonomy", as this will lead one to conclude that party autonomy is a principle with no flexibility.

To this end, party autonomy, as the word connotes, is a fundamental principle in international commercial arbitration, with significant practical applicability. However, it admits some limitations, which have been discussed in section 6 of this article. These limitations are the exceptions to party autonomy in commercial arbitration. Hence, the principle of party autonomy is arguably not cast in iron. Unless the parties to the arbitration comply with the essential validity of arbitration agreement, as highlighted in this article, the functional application of the doctrine of party autonomy may be a myth rather than reality. 